\title{
Jurist-Diction
}

Volume 2 No. 5, September 2019

Histori artikel: Submit 21 Juli 2019; Diterima 20 Agustus 2019; Diterbitkan online 1 September 2019.

\section{Pelanggaran Bea Perolehan Hak Atas Tanah Dan Bangunan Dalam Jual Beli Tanah}

\author{
Aldi Luna Ramadhan \\ aldir465@gmail.com \\ Universitas Airlangga
}

\begin{abstract}
As a developing country, Indonesia needs substantial funds to carry out the development. One way to increase state income is to collect taxes to the society. Fees for Acquisition of Land and Building Rights (BPHTB) is one of the taxes collected by the Regional Government and used to carry out the regional development. In the collection process, taxpayers often do recognition of prices for paying $B P H T B$. The price recognition is that the taxpayer does not calculate the tax with the appropriate basis of imposition that stipulated in the Act. The problems that occur regarding price recognition also seem to be ignored by the taxpayer. The research method used in this thesis is normative juridical research, which is focused on analyzing a legal problem against the norms or rules of positive law that apply. The results of this study concluded that there were still violations committed by taxpayers on the implementation of BPHTB payments. It is recommended for taxpayers to make real payments based on existing rules and can be carried out socialization to the public regarding the importance of BPHTB tax in the state income.
\end{abstract}

Keywords: Tax Collection; BPHTB; Revenue Recognition; Imposition of BPHTB.

\begin{abstract}
Abstrak
Sebagai negara yang sedang menyelenggarakan pembangunan, Negara Indonesia membutuhkan dana yang cukup besar dalam menyelenggarakan pembangunan tersebut. Salah satu cara meningkatkan pemasukan Negara salah satunya dapat melakukan pemungutan pajak kepada masyarakat. Bea Perolehan Hak Atas Tanah dan Bangunan (BPHTB) merupakan salah satu pajak yang dipungut oleh Pemerintah Daerah dan digunakan untuk menyelenggarakan pembangunan didaerah. Dalam proses pemungutannya sering kali wajib pajak melakukan pengakuan harga dalam membayar BPHTB. Pengakuan harga yang dimaksud yaitu wajib pajak tidak menghitung dengan dasar pengenaan yang seharusnya yang telah diatur dalam Undang-Undang. Permasalahan mengenai pengakuan harga pun seakan akan diabaikan begitu saja oleh wajib pajak. Metode penelitian skripsi ini adalah penelitian yuridis normative, yaitu penelitian yang difokuskan untuk menganalisa suatu permasalahan hukum terhadap norma-norma atau kaidah-kaidah hukum positif yang berlaku. Hasil penelitian ini menyimpulkan bahwa masih ada pelanggaran yang dilakukan oleh wajib pajak terhadap pelaksanaan pembayaran BPHTB. Disarankan untuk wajib pajak agar melakukan pembayaran dengan sebenarbenarnya berdasarkan dengan aturan yang ada serta dapat dilakukan sosialisasi terhadap masyarakat mengenai pentingnya pajak BPHTB dalam pemasukan Negara.
\end{abstract}

Kata Kunci: Pemungutan Pajak; BPHTB; Pengakuan Harga; Dasar Pengenaan BPHTB.

\section{Pendahuluan}

Tanah merupakan suatu hal yang dibutuhkan oleh manusia untuk memenuhi kebutuhan hidup. Manusia hidup dan melakukan aktifitas setiap saat diatas tanah, maka dari itu dapat dikatakan manusia selalu berhubungan dengan tanah baik secara 
langsung maupun secara tidak langsung. Tanah merupakan kebutuhan dasar yang harus dipenuhi oleh manusia selain makanan dan pakaian.

Begitu berharganya tanah, sehingga manusia akan selalu berupaya untuk mendapatkan tanah, dari upaya membeli dari pemilik tanah, melakukan tukar menukar, dan membuka hutan atau ladang. Perbuatan-perbuatan di atas mengakibatkan pemilikan dan hak penguasaan tanah beralih dari satu pihak ke pihak yang lain. ${ }^{1}$

Peralihan hak atas tanah dan bangunan berkaitan erat dengan kepastian hukum dan ditandai oleh adanya bukti atas peralihan hak tersebut. Untuk memberikan kekuatan dan kepastian hukum pemilikan tanah dan bangunan setiap peralihan hak atas tanah dan atau bangunan harus dilakukan secara tertulis dengan akta yang dibuat oleh pejabat yang berwenang, serta wajib didaftarkan pada instansi yang berwenang, yaitu Kantor Pertanahan Kabupaten/Kota setempat. Dengan demikian, hak atas tanah dan bangunan secara sah ada pada pihak yang memperoleh hak tersebut dan dapat dipertahankan terhadap semua pihak. ${ }^{2}$

Betapa besar peranan tanah dalam dinamika pembangunan, maka di dalam Pasal 33 ayat (3) Undang-Undang Dasar 1945 disebutkan bahwa bumi, air dan kekayaan alam yang terkadung didalamnya dikuasai oleh negara dan dipergunakan sebesar-besarnya untuk kemakmuran rakyat. Pasal 1 ayat (2)Undang-Undang Nomor 5 Tahun 1960 tentang Peraturan Dasar Pokok-Pokok Agraria menyatakan bahwa seluruh bumi, air dan ruang angkasa, termasuk kekayaan alam yang terkandung didalamnya dalam wilayah Republik Indonesia sebagai karunia Tuhan Yang Maha Esa adalah bumi, air dan ruang angkasa bangsa Indonesia dan merupakan kekayaan nasional. Maka dari itu peralihan hak atas tanah dan bangunan menimbulkan adanya hak dan kewajiban bagi pihak yang mengalihkan maupun pihak yang menerima peralihan hak. Kewajiban tersebut dimana setiap orang pribadi atau badan yang memperoleh hak atas tanah dan bangunan wajib menyerahkan sebagian nilai ekonomis yang diperolehnya kepada negara melalui pembayaran pajak.

\footnotetext{
${ }^{1}$ Marihot Pahala Siahaan, Bea Perolehan Hak atas Tanah dan Bangunan (Raja Grafindo Persada 2003) (Selanjutnya disebut Marihot Pahala Siahaan I).[5].

2 ibid.
} 
Sebagai negara yang sedang giat menyelenggarakan pembangunan, pastinya Pemerintah Indonesia membutuhkan banyak dana untuk membiayai pengeluaran Pemerintah. Banyak cara yang dapat dilakukan Pemerintah untuk meningkatkan seumber penerimaan negara, salah satunya yaitu melalui pemungutan pajak. Pajak merupakan sumber pendapatan negara yang cukup potensial untuk membiayai pembangunan.

Pajak sebagai sumber penerimaan negara harus menjadi penerimaan utama karena sumber-sumber penerimaan yang lain, selain seperti pajak, pendapatan pengelolaan sumber alam sangat terbatas, bisa berkurang bahkan habis. Oleh karena itu, kesadaran rakyat membayar pajak harus ditumbuhkembangkan secara terus menerus agar pajak nantinya sebagai sumber utama untuk membiayai pembangunan. ${ }^{3}$

Besarnya peranan yang diberikan oleh pajak sebagai sumber dana dalam Pembangunan Nasional, menyebabkan perlunya penggalian potensi pajak yang ada dalam masyarakat sesuai dengan situasi dan kondisi perekonomian serta perkembangan bangsa ini. Salah satu sumber potensi pajak yang patut digali sesuai dengan situasi dan kondisi perekonomian serta perkembangan pembangunan bangsa Indonesia sekarang ini adalah jenis pajak Bea Perolehan Hak atas Tanah dan Bangunan (BPHTB). ${ }^{4}$

Bea Perolehan Hak atas Tanah dan Bangunan (BPHTB) merupakan salah satu sumber potensi pajak yang patut digali sesuai situasi dan kondisi perekonomian serta perkembangan bangsa sekarang ini. Namun pemungutan atau pengenaan Bea Perolehan Hak atas Tanah dan Bangunan harus tetap memperhatikan aspek keadilan bagi masyarakat golongan ekonomi lemah dan masyarakat berpenghasilan rendah yang diwujudkan dalam nilai perolehan hak atas tanah dan bangunan yang tidak dikenakan pajak.

Salah satu tujuan dari pelaksanaan pengutan Bea Perolehan Hak atas Tanah dan Bangunan yaitu untuk memperkuat potensi sumber penerimaan negara yang

${ }^{3}$ Setu Setiawan, Perpajakan Indonesia Edisi 2009 (Universitas Muhammadiyah Malang Press 2009).[1].

${ }^{4}$ Marihot Pahala Siahaan I. Op.Cit.[6]. 
stabil dan dapat dipergunakan untuk membiayai pembangunan daerah. Walaupun secara nasional BPHTB tergolong sebagai pemasukan dari sector pajak yang tidak cukup besar dibandingkan dengan jenis pajak lain, tetapi sekecil apapun bentuk pemasukan pajak tersebut tetap berguna dalam menopong kas negara dan dapat meningkatkan kesejahteraan masyarakat.

Bea Perolehan Hak atas Tanah dan Bangunan sebelum diberlakukannya Undang-Undang Nomor 28 Tahun 2009 tentang Pajak Daerah dan Retribusi Daerah merupakan pajak yang dipungut oleh pemerintah pusat. Tetapi sejak adanya Undang-Undang Nomor 28 tahun 2009 tentang Pajak Daerah dan Retribusi Daerah maka terdapat pembaruan disektor pajak daerah yang dipungut oleh Pemerintah Daerah. Namun dalam Pasal 95 ayat (1) Undang-Undang Nomor 28 Tahun 2009 menyebutkan bahwa pajak harus ditetapkan terlebih dahulu dengan Peraturan Daerah (selanjutnya disebut Perda). Maka dari itu, Pemerintah Daerah harus terlebih dahulu memiliki Perda yang mengatur tentang BPHTB, jika tidak memiliki Perda maka Pemerintah Daerah tidak boleh memungut BPHTB.

Kota Mataram merupakan salah satu kota yang telah memiliki perda yang mengatur mengenai BPHTB yang disesuaikan dengan Undang-Undang Nomor 28 Tahun 2009, yaitu Peraturan Daerah Kota Mataram Nomor 7 Tahun 2018 tentang Perubahan Kedua Atas Peraturan Daerah Kota Mataram Nomor 12 Tahun 2010 Tentang Bea Perolehan Hak atas Tanah dan Bangunan (selanjutnya disebut Perda Nomor 7 Tahun 2018). Dengan demikian, Kota Mataram menjadi Kota yang tidak akan kehilangan potensi pendapatan daerahnya.

Pemungutan BPHTB dilakukan berdasarkan sistem Self Assessment. Dalam sistem ini wajib pajak diberi wewenang dan kepercayaan untuk menghitung sendiri, membayar serta melaporkan pajak yang terutang atau yang harus dibayar. Dengan sistem ini diharapkan masyarakat bisa dengan mudah memenuhi kewajiban pajaknya dan meningkatkan kesadaran pajak masyarakat, terutama pajak yang timbul pada saat terjadinya perolehan hak atas tanah dan bangunan. ${ }^{5}$

5 ibid. [45]. 
Dalam sistem self assessment wajib pajak merupakan subyek atau para pelaku perpajakan, sehingga memiliki nilai positif dalam mencerdaskan wajib pajak. Namun disisi lain sistem ini mempunyai kelemahan, yaitu tidak semua wajib pajak mengerti dengan prosedur membayar pajak yang baik dan benar. Kurangnya pemahaman seperti ini yang mengakibatkan wajib pajak kesulitan dalam menghitung, memperhitungkan, melaporkan, dan membayar pajak terhutang kepada negara.

\section{Dasar Pengenaan dan Pemungutan BPHTB}

Dalam pengenaan dan pemungutan pajak, satu hal mendasar yang harus diketahui adalah dasar pengenaan pajak. Sesuai dengan Pasal 87 ayat (1) Undang-Undang Nomor 28 Tahun 2009, yang menjadi dasar pengenaan pajak pada BPHTB adalah Nilai Perolehan Objek Pajak (NPOP). NPOP adalah besaran nilai/ harga objek pajak yang dipergunakan sebagai dasar pengenaan pajak. Karena pada dasarnya ada 15 jenis perolehan hak atas tanah dan bangunan yang menjadi objek pajak, maka atas setiap jenis peralihan hak tersebut harus ditentukan NPOPnya. Pasal 87 ayat (2) menentukan apa yang menjadi NPOP sebagai dasar pengenaan pajak pada masing-masing jenis perolehan hak, sebagai berikut :

a. Jual beli, yang menjadi NPOP adalah harga transaksi;

b. Tukar menukar, yang menjadi NPOP adalah nilai pasar;

c. Hibah, yang menjadi NPOP adalah nilai pasar;

d. Hibah wasiat, yang menjadi NPOP adalah nilai pasar;

e. Waris, yang menjadi NPOP adalah nilai pasar;

f. Pemasukan dalam perseroan atau badan hukum lainnya, yang menjadi NPOP adalah nilai pasar;

g. Pemisahan hak yang mengakibatkan peralihan, yang menjadi NPOP adalah nilai pasar;

h. Peralihan hak sebagai pelaksanaan putusan hakim yang mempunyai kekuatan hukum tetap, yang menjadi NPOP aladah nilai pasar;

i. Pemberian hak baru atas tanah sebagai kelanjutan dari pelepasan hak, yang menjadi NPOP adalah nilai pasar;

j. Pemberian hak baru atas tanah di luar pelepasan hak, yang menjadi NPOP adalah nilai pasar;

k. Penggabungan usaha, yang menjadi NPOP adalah nilai pasar;

1. Peleburan usaha, yang menjadi NPOP adalah nilai pasar;

m. Pemekaran usaha, yang menjadi NPOP adalah nilai pasar; 
n. Hadiah, yang menjadi NPOP adalah nilai pasar;

o. Penunjukan pembeli dalam lelang, yang menjadi NPOP adalah harga transaksi yang tercantum dalam risalah lelang.

Jika NPOP sebagai mana yang dimaksud di atas tidak diketahui atau lebih rendah daripada NJOP yang digunakan dalam pengenaan PBB pada tahun terjadi perolehan, dasar pengenaan yang dipakai adalah NJOP PBB. Hal ini menunjukkan adanya kaitan antara BPHTB dengan PBB, di mana NJOP yang ada pada dasarnya merupakan dasar pengenaan pajak pada PBB juga dijadikan sebagai dasar dalam menentukan dasar pengenaan pajak pada BPHTB.

Penggunaan NJOP sebagai pembanding terhadap harga transaksi atau nilai pasar sebenarnya wajar karena pada dasarnya NJOP mencerminkan nilai pasar dari objek pajak yang diperoleh. Pengertian dari NJOP sendiri yaitu, harga rata-rata yang diperoleh dari transaksi jual beli yang terjadi secara wajar, dan bilamana tidak terdapat transaksi jual beli, NJOP ditentukan melalui perbandingan harga dengan objek lain yang sejenis, atau nilai perolehan baru, atau NJOP pengganti.

Dalam sistem perpajakan Indonesia diatur adanya batasan dasar pengenaan pajak yang tidak dikenakan pajak. Pada pajak objektif, batasan pengenaan pajak ini didasarkan pada nilai objek pajak, dimana apabila kurang dari batasan dimaksud maka akan dibebaskan pajaknya, sedangkan pada pajak subjektif batasan nilai dari objek akan membuat apakah seorang wajib pajak dikenakan pajak atau tidak. Untuk asas keadilan, maka apabila atas suatu objek pajak memiliki nilai di atas batas tidak kena pajak yang ditetapkan, atas objek pajak tersebut hanya akan dikenakan pajak atas selisih dari nilai objek pajak dengan nilai batasan tidak kena pajak. Yang termasuk batas tidak kena pajak pada pajak objektif adalah Nilai Objek Pajak Tidak Kena Pajak (NJOPTKP) dan Nilai Perolehan Objek Pajak Tidak Kena Pajak (NPOPTKP). ${ }^{6}$

Sesuai dengan Undang-Undang Nomor 28 Tahun 2009 Pasal 87 ayat 4 dan 5, besaran NPOPTKP ditetapkan paling rendah sebesar Rp. 60.000.000,00

${ }^{6}$ Marihot Pahala Siahaan, Bea Perolehan Hak Atas Tanah dan Bangunan (BPHTB) sebagai pajak daerah (Sagung Seto) (selanjutnya disebut Marihot Pahala Siahaan II).[110] 
(enam puluh juta rupiah) untuk setiap wajib pajak. NPOPTKP pada dasarnya merupakan suatu besaran tertentu dari nilai perolehan objek pajak (NPOP) yang tidak dikenakan pajak. Hal ini berarti apabila NPOP yang menjadi dasar pengenaan pajak kurang dari besaran NPOPTKP yang ditetapkan suatu kabupaten/ kota, maka atas objek pajak tersebut tidak ada BPHTB yang harus dibayar oleh wajib pajak. Sementara apabila NPOP besarnya lebih dari NPOPTKP yang ditetapkan maka objek pajak tersebut akan dikenakan pajak, di mana besarnya pajak terutang dihitung dari selisih antara NPOP dan NPOPTKP. ${ }^{7}$ Di Kota Mataram sendiri menurut Pasal 8 ayat (1) Perda Nomor 12 Tahun 2010 tentang BPHTB menentukan bahwa besaran NPOPTKP ditetapkan sebesar Rp. 60.000.000,00 (enam puluh juta rupiah) untuk setiap wajib pajak.

Berdasarkan ketentuan Undang-Undang Nomor 21 Tahun 1997, tarif pajak BPHTB ditetapkan sebesar 5\%. Hal ini menunjukkan pada saat masih menjadi pajak pusat, tarif yang digunakan dalam perhitungan pajak adalah tarif tunggal yang bersifat proporsional. Tarif pajak ini diberlakukan secara nasional untuk semua jenis perolehan hak atas tanah dan/atau bangunan. Namun pada ketentuan tentang tarif pajak dalam Undang-Undang Nomor 28 Tahun 2009 mengalami perubahan. Yang dimana pada Pasal 88 dinyatakan bahwa tarif BPHTB ditetapkan paling tinggi 5\%. Ketentuan tentang tarif BPHTB ini tidak secara tegas menentukan apakah menggunakan tarif pajak proporsional untuk semua jenis perolehan hak. ${ }^{8}$ Dengan kata lain ada kemungkinan bagi pemerintah daerah untuk mengatur besaran tarif pajak yang berbeda untuk berbagai jenis perolehan hak atas tanah atau bangunan yang menjadi objek pajak. Satu syarat yang harus dipatuhi ialah, besaran tarif pajak tersebut tidak boleh lebih besar dari 5\%.

Cara perhitungan pajak BPHTB yang terutang dihitung dengan cara mengalikan tarif pajak dengan dasar pengenaan pajak setelah dikurangi NPOPTKP, secara umum perhitungan BPHTB adalah sesuai dengan rumus sebagai berikut :

\footnotetext{
7 ibid.[111].

8 ibid.[122].
} 


\section{Pajak Terutang $=\quad$ Tarif Pajak x Dasar Pengenaan Pajak $=$ Tarif Pajak $x$ (NPOP - NPOPTKP)}

Apabila NPOP tidak diketahui atau lebih kecil dari pada NJOP, rumus perhitungan BPHTB harus disesuaikan menjadi sebagai berikut :

\section{Pajak Terhutang $=$ Tarif Pajak $\mathbf{x}$ Dasar Pengenaan Pajak $=$ Tarif Pajak x (NJOP - NPOPTKP)}

Dengan menetapkan pemungutan BPHTB menggunakan self assessment maka wajib pajak diberi kepercayaan untuk menghitung dan membayar sendiri pajak yang terutang dengan menggunakan Surat Setoran Pajak Daerah (SSPD), dan melaporkannya tanpa mendasarkan diterbitkannya Surat Ketetapan Pajak Daerah. SSPD adalah bukti pembayaran atau penyetoran pajak yang telah dilakukan dengan menggunakan formulir ke kas daerah melalui tempat pembayaran BPHTB. Setelah itu petugas pajak melakukan verifikasi kelengkapan pembayaran wajib pajak untuk memastikan bahwa data atau dokumen yang diserahkan sudah sesuai dan benar. Setelah dipastikan bahwa dokumen yang diajukan telah disetujui, maka dilanjutkan dengan proses validasi. Layanan validasi memastikan bahwa data yang diajukan telah layak dan sesuai dengan kriteria yang diajukan. Setelah itu wajib pajak dapat melakukan pembayaran pajak kepada petugas pajak. Untuk lebih mudahnya mengetahui prosedur pemungutan BPHTB, dapat dilihat dalam skema dibawah ini;

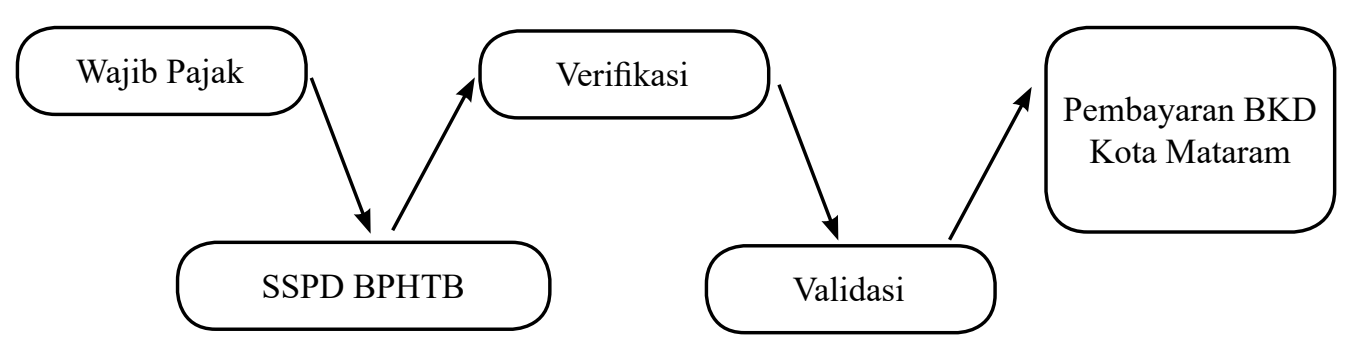

\section{Bentuk pelanggaran pemungutan BPHTB dan upaya penyelesaiannya}

Pemungutan BPHTB sebagai Pajak Daerah dapat berlangsung dengan baik apabila wajib pajak dengan penuh tanggung jawab melaksanakan semua kewajiban perpajakannya dengan benar. Hanya saja kondisi ideal ini tidak sepenuhnya dapat tercapai apabila wajib pajak karena kesengajaannya atau kealpaannya tidak 
memenuhi kewajiban sebagaimana mestinya. Berhasil atau tidaknya pelaksanaan pemungutan pajak banyak tergantung pada wajib pajak sendiri. Dengan ditetapkannya system self assessment menjadi sistem perpajakan nasional maka wajib pajak wajib untuk melakukan perhitungan jumlah pajaknya sendiri dengan menggunakan Surat Setoran Pajak Daerah (SSPD) BPHTB dan melaporkan tanpa berdasarkan di terbitkannya Surat Ketetapan Pajak dan petugas pajak (fiskus) berfungsi sebagai pengawas.

Berdasarkan penelitian yang penulis lakukan di Badan Keuangan Daerah Kota Mataram, salah satu potensi terjadinya pelanggaran yang dilakukan oleh wajib pajak yaitu, pengakuan harga. Pengakuan harga yang dimaksudkan yaitu wajib pajak tidak mencantumkan harga jual beli asli yang telah disepakati antara penjual dengan pembeli, melainkan wajib pajak menggunakan NJOP sebagai dasar pengenaan BPHTB. ${ }^{9}$ Yulian Hadi Iskandar selaku Kasubid Perhitungan dan Penetapan menyatakan bahwa, wajib pajak melakukan pengakuan harga tersebut karena didasari dengan kebiasaan yang dilakukan oleh wajib pajak yang lain agar mendapatkan harga pajak yang lebih sedikit. Dalam Perda Kota Mataram Nomor 12 Tahun 2010 tentang Bea Perolehan Hak Atas Tanah dan Bangunan sudah jelas dikatakan bahwasannya dasar pengenaan BPHTB adalah NPOP, dan nilai perolehan objek pajak dalam jual beli tanah adalah berdasarkan dengan harga transaksi atau nilai pasar. Dengan ini dapat disimpulkan bahwa NPOP dalam jual beli yang diketahui tidak sesuai dengan harga transaksi atau nilai pasar merupakan sebuah pelanggaran yang dilakukan oleh wajib pajak. Menurut Pasal 87 Undang-Undang Nomor 28 Tahun 2009 memang menyatakan bahwa jika NPOP sebagaimana dimaksud tidak diketahui atau lebih rendah dari NJOP, maka yang digunakan dalam pengenaan PBB pada tahun terjadinya perolehan, dasar pengenaan yang dipakai adalah NJOP PBB. Tetapi logikanya, pada transaksi jual beli yang menjadi NPOP salah satunya adalah harga transaksi. Jadi tidak mungkin wajib pajak tidak mengetahui harga transaksi jual beli tersebut, karena yang menentukan harga jual beli tersebut adalah wajib pajak itu sendiri.

\footnotetext{
9 Wawancara dengan Kasubid Perhitungan dan Penetapan Badan Keuangan Daerah Kota Mataram, Tgl. 27 Maret 2019.
} 
Selain itu, Yulian Hadi Iskandar juga mengatakan bahwa wajib pajak yang menggunakan NJOP sebagai dasar pengenaan BPHTB mereka juga tidak mengunakan NJOP yang tepat sesuai dengan lokasi tanah mereka. Kebanyakan wajib pajak mencari harga NJOP yang terkecil untuk dijadikan dasar pengenaan BPHTB. Akibat dari pelanggaran yang dilakukan wajib pajak tersebut bagi pemerintah daerah sudah jelas menimbulkan kerugian pajak yang seharusnya bisa berdampak baik bagi pemasukan daerah. Wajib pajak sebagai yang melanggar juga mendapatkan sanksi administratif dalam bentuk Surat Ketetapan Pajak Daerah Kurang Bayar (SKPDKB) yang dikeluarkan oleh Kepala Daerah.

Dalam proses pengenaan dan pemungutan pajak ada satu tahapyang memegang peranan penting agar wajib pajak memiliki kewajiban membayar pajak. Hal ini yaitu penetapan pajak. Dalam hukum pajak masalah penetapan pajak memegang peran penting karena tanpa ditetapkan oleh pihak yang ditentukan oleh undangundang, tidak ada pajak terutang yang harus dibayar oleh wajib pajak. Penetapan pajak ini memiliki kaitan erat dengan saat timbulnya utang pajak. Dalam sistem self assessment, kewenangan untuk menghitung sendiri pajak terutang menunjukkan adanya kewenangan yang diberikan oleh Undang-Undang pajak kepada wajib pajak untuk menetapkan sendiri besarnya pajak terutang yang harus dibayar oleh wajib pajak. Yang menentukan bahwa pajak terutang timbul yaitu apabila objek pajak atau taatbestand telah terpenuhi, tanpa perlu adanya surat ketetapan pajak yang diterbitkan oleh fiskus. Wajib pajak yang memenuhi taatbestand pajak secara otomatis memiliki utang pajak, dimana besarnya pajak terutang ditetapkan sendiri oleh wajib pajak. Wajib pajak tersebut kemudian harus membayar pajak tersebut untuk menghapuskan utang pajak tersebut. ${ }^{10}$

Pada sitem self assessment, fiskus juga menerbitkan surat ketetapan pajak, hanya saja surat ketetapan pajak tersebut tidak bersifat menimbulkan utang pajak melainkan hanya sebagai koreksi atas penetapan pajak yang telah dilakukan oleh wajib pajak. Fiskus akan melakukan pemeriksaan terhadap wajib pajak untuk

\footnotetext{
${ }^{10}$ Marihot Pahala Siahaan, Seri Hukum Pajak Indonesia: Hukum Pajak Formal (Graha Ilmu 2010) (selanjutnya disebut Marihot Pahala Siahaan III).[83].
} 
memastikan apakah wajib pajak telah membayar dengan sesuai undang-undang atau tidak. Berdasarkan hasil pemeriksaan, fiskus kemudian melakukan penetapan pajak dengan mengeluarkan surat ketetapan pajak yang dapat berarti wajib pajak kurang bayar, lebih bayar, telah sesuai atau nihil. Penetapan pajak ini bersifat koreksi terhadap penetapan pajak yang telah dilakukan wajib pajak maupun penetuan bahwa penetapan pajak telah sesuai dengan aturan undang-undang. ${ }^{11}$ Jenis pajak yang ditetapkan dipungut berdasarkan sistem self assessment, fiskus akan menetapkan pajak setelah melakukan pemeriksaan atas perhitungan dan pembayaran pajak daerah yang telah dilakukan oleh wajib pajak dan telah dilaporkan dalam Surat Pemberitahuan Pajak Daerah. Penetapan pajak dilakukan dengan menerbitkan surat ketetapan pajak, adapun surat ketetapan tersebut sebagai berikut :

1. Surat Ketetapan Pajak Daerah Kurang Bayar (SKPDKB).

Menurut Pasal 1 angka 55 Undang-Undang Nomor 28 Tahun 2009 pengertian dari SKPDKB adalah surat ketetapan pajak yang menentukan besarnya jumlah pokok pajak, jumlah kredit pajak, jumlah kekurangan pembayaran pajak, besarnya sanksi administratif, dan jumlah pajak yang masih harus dibayar. Apabila wajib pajak tidak melaksanakan kewajibannya dengan benar maka fiskus dapat memberikan Surat Ketetapan Pajak Daerah Kurang Bayar (SKPDKB). Sesuai dengan Pasal 97 ayat 1 Undang-Undang Nomor 28 Tahun 2009, dalam jangka waktu lima tahun sesudah saat terutangnya pajak, kepala daerah dapat menerbitkan SKPDKB dalam hal terdapat keadaan sebagaimana di bawah ini:

a) Jika berdasarkan hasil pemeriksaan atau keterangan lain, pajak yang terutang tidak atau kurang dibayar.

b) Jika SPTPD tidak disampaikan kepada kepala daerah dalam jangka waktu tertentu dan setelah ditegur secara tertulis tidak disampaikan pada waktunya sebagaimana ditentukan dalam surat teguran.

c) Jika kewajiban mengisi SPTPD tidak dipenuhi, pajak yang terutang dihitung secara jabatan.

${ }^{11}$ ibid. $[84]$. 
2. Surat Ketetapan Pajak Daerah Kurang Bayar Tambahan (SKPDKBT).

Sesuai dengan Pasal 97 ayat (1) huruf b, dalam jangka waktu lima tahun sesudah saat terutangnya pajak kepala daerah dapat menerbitkan Surat Ketetapan Pajak Daerah Kurang Bayar Tambahan (SKPDKBT) apabila ditemukan data baru dan/atau data yang semula belum terungkap yang menyebabkan penambahan jumlah pajak yang terutang. Definisi SKPDKBT dalam Pasal 1 angka 56 Undang-Undang Nomor 28 Tahun 2009 adalah surat ketetapan pajak yang menentukan tambahan atas jumlah pajak yang telah ditetapkan. Sesuai dengan Pasal 97 ayat (3) Undang-Undang Nomor 28 Tahun 2009 yang menyatakan bahwa jumlah kekurangan pajak yang terutang dalam SKPDKBT sebagaimana dimaksud pada ayat (1) huruf b dikenakan sanksi administratif berupa kenaikan sebesar $100 \%$ dari jumlah kekurangan pajak tersebut. Wajib pajak tidak memenuhi kewajiban perpajakannya dengan benar dalam hal dengan ditemukannya data baru dan atau data yang semula belum terungkap yang berasal dari hasil pemeriksaan, sehingga pajak yang terutang bertambah. Terhadap wajib pajak dikenakan sanksi administratif sebesar 100\% dari jumlah kekurangan pajak.

3. Surat Ketetapan Pajak Daerah Nihil (SKPDN)

Definisi SKPDN dapat dilihat dalam Pasal 1 angka 57 Undang-Undang Nomor 28 Tahun 2009, yaitu SKPDN adalah surat ketetapan pajak yang menentukan jumlah pokok pajak sama besarnya dengan jumlah kredit pajak atau pajak tidak terutang dan tidak ada kredit pajak. Menurut Pasal 97 ayat (1) huruf c Undang-Undang Nomor 28 Tahun 2009, yaitu dalam jangka waktu lima tahun sesudah saat terutangnya pajak, kepala daerah dapat menerbitkan Surat Ketetapan Pajak Daerah Nihil (SKPDN) apabila jumlah pajak yang terutang sama besarnya dengan jumlah kredit pajak atau pajak tidak terutang dan tidak ada kredit pajak.

4. Surat Ketetapan Pajak Daerah Lebih Bayar (SKPDLB)

Dalam proses pemungutan BPHTB dapat dimungkinkan terjadi kelebihan pembayaran pajak terutang. Apabila berdasarkan pemeriksaan ternyata petugas pajak daerah menemukan data dan fakta yang menyatakan bahwa terjadi 
kelebihan pembayaran pajak, atas kelebihan pembayaran pajak tersebut harus diterbitkan Surat Ketetapan Pajak Daerah Lebih Bayar (SKPDLB). Menurut Pasal 1 angka 58 Undang-Undang Nomor 28 Tahun 2009 yang dimaksud dengan SKPDLB yaitu surat ketetapan pajak yang menentukan jumlah kelebihan pembayaran pajak karena jumlah kredit pajak lebih besar daripada pajak yang terutang atau seharusnya tidak terutang. SKPDLB pada dasarnya merupakan salah satu bentuk ketetapan pajak yang dapat diterbitkan oleh bupati/walikota dalam rangka memberikan kepastian hukum atas pembayaran pajak yang telah dilakukan oleh wajib pajak.

Dalam pelanggaran yang sering terjadi dalam pembayaran BPHTB di Badan Keuangan Daerah Kota Mataram yaitu dengan pengakuan harga, yang dimana wajib pajak tidak mencantumkan harga asli pada transaksi jual beli dalam pembayaran BPHTB. Wajib pajak yang terbukti melakukan hal tersebut maka petugas pajak dapat menerbitkan Surat Ketetapan Pajak Daerah Kurang Bayar (SKPDKB). Hal ini didasarkan pada Pasal 97 ayat (1) huruf a angka 1 Undang-Undang Nomor 28 Tahun 2009, yaitu kepala daerah dapat menerbitkan SKPDKB dalam hal jika berdasarkan hasil pemeriksaan atau keterangan lain, pajak yang terutang tidak atau kurang bayar. Beradasarkan Pasal 97 ayat 2 Undang-Undang Nomor 28 Tahun 2009, yang menyatakan bahwa jumlah kekurangan pajak yang terutang dalam SKPDKB yang dikeluarkan dalam hal berdasarkan hasil pemeriksaan atau keterangan lain ternyata pajak yang terutang tidak atau kurang dibayar serta SKPDKB dikeluarkan dalam hal SSPD tidak disampaikan kepada pejabat yang berwenang dalam jangka waktu masa pajak dan setelah ditegur secara tertulis tidak disampaikan pada waktunya sebagaimana ditetukan dalam surat teguran, dikenakan sanksi administratif berupa bunga sebesar $2 \%$ per sebulan dihitung dari pajak yang kurang atau terlambat bayar untuk jangka paling lama 24 bulan dihitung sejak saat terhutangnya pajak. Sanksi administratif berupa bunga dihitung sejak saat terutangnya pajak sampai dengan diterbitkannya SKPDKB. SKPDKB setelah diterbitkan mempunyai jangka waktu 1 (satu) bulan untuk wajib pajak membayarkan kekurangan pajaknya. Jika wajib pajak dalam kurun waktu 1 (satu) bulan tidak membayarkan kekurangannya 
maka petugas pajak dapat menerbitkan Surat Tagihan Pajak Daerah (STPD). STPD adalah surat untuk melakukan tagihan pajak dan/atau sanksi administratif berupa bunga dan/atau denda. Penerbitan STPD dapat dilakukan apabila berdasarkan hasil penelitian yang dilakukan kantor pajak terbukti SSPD terdapat kekurangan pembayaran pajak sebagai akibat salah tulis dan/atau salah hitung. Jadi wajib pajak tersebut harus membayar sanksi SKPDKB dan STPD. Untuk lebih mudahnya mengetahui penyelesaian bentuk pelanggaran pembayaran BPHTB, dapat dilihat dalam skema dibawah ini;

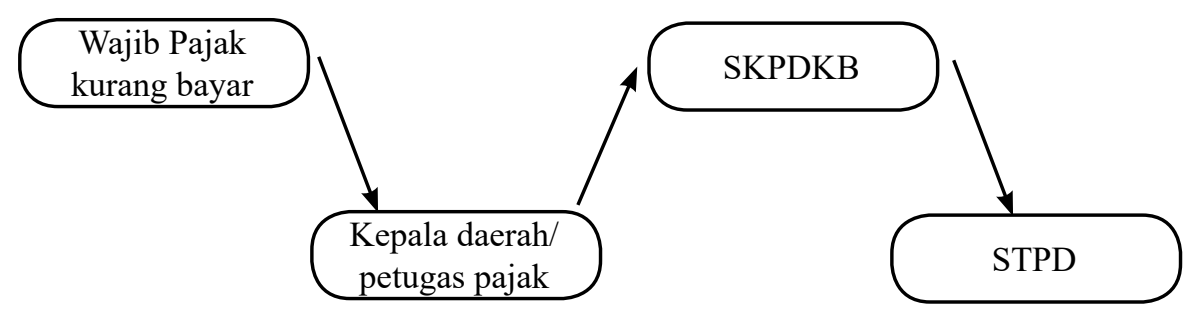

Dalam hal perlindungan hukum bagi wajib pajak, berdasarkan Pasal 103 Undang-Undang Nomor 28 Tahun 2009 menyatakan bahwa, wajib pajak dapat mengajukan keberatan atas suatu SPPT, SKPD, SKPDKB, SKPDKBT, SKPDLB, SKPDN, dan pemotongan atau pemungutan oleh pihak ketiga berdasarkan ketentuan peraturan perundang-undangan perpajakan daerah. Keberatan atas ketetapan pajak merupakan hak wajib pajak yang dijamin oleh Undang-Undang dalam rangka keadilan. Keberatan dapat dilakukan oleh wajib pajak apabila wajib pajak merasa tidak puas atas penetapan pajak yang dilakukan oleh fiskus.

Tata cara pengajuan keberatan:

a) Keberatan diajukan secara tertulis dalam Bahasa Indonesia dengan mengemukakan jumlah pajak yang terhutang menurut perhitungan wajib pajak dan disertai alasan-alasan yang jelas. Maksudnya adalah wajib pajak mengemukan dengan data atau bukti bahwa jumlah pajak yang tercantum dalam surat ketetapan pajak tidak benar.

b) Pengajuan surat permohonan keberatan dilakukan oleh wajib oajak dengan melampirkan bukti pendukung, seperti fotokoip SSPD BPHTB, asli SKPDKB/ SKPDKBT/SKPDLB/SKPDN, fotokopi akta, fotokopi KTP, dan bukti pendukung lain.

c) Keberatan harus diajukan dalam jangka waktu paling lama tiga bulan sejak tanggal diterimanya SKPDKB, SKPDKBT, SKPDLB, SKPDN oleh wajib pajak.

d) Keberatan dapat dilakukan apabila wajib pajak telah membayar paling sedikit 
sejumlah yang telah disetujui wajib pajak.

e) Keberatan yang tidak memenuhi persyaratan diatas tidak diangap sebagai surat keberatan sehingga tidak dapat dipertimbangkan.

f) Tanda penerimaan surat keberatan yang diberikan oleh bupati/walikota atau pejabat yang ditunjuk tercatat dinyatakan sebagai tanda bukti penerimaan surat keberatan.

Pada dasarnya keputusan keberatan bukan merupakan produk hukum akhir dalam dalam penyelesaian sengketa pajak, karena kepada wajib pajak masih diberikan hak untuk melakukan pembelaan terhadap keputusan keberatan tersebut. Apabila wajib pajak tidak setuju dengan keputusan keberatan yang diterima, maka wajib pajak mempunyai hak untuk mengajukan banding kepada badan peradilan pajak yang ditunjuk atau ditentukan oleh Undang-Undang pajak.

Pengajuan banding hanya dilakukan kepada Pengadilan Pajak terhadap keputusan mengenai keberatanya yang ditetapkan oleh bupati/walikota atau pejabat yang berwenang. Permohonan banding diajukan secara tertulis dengan Bahasa Indonesia, dengan alasan yang jelas dalam jangka waktu tiga bulan sejak keputusan diterima. Putusan Pengadilan Pajak merupakan putusan akhir dan mempunyai kekuatan hukum tetap. Putusan Pengadilan Pajak diambil berdasarkan hasil penilaian pembuktian, peraturan perundang-undangan perpajakan, serta berdasarkan keyakinan hakim.

\section{Kesimpulan}

Dalam pengenaan dan pemungutan pajak, satu hal mendasar yang harus diketahui adalah dasar pengenaan pajak. Sesuai dengan Pasal 87 ayat (1) Undang-Undang Nomor 28 Tahun 2009, yang menjadi dasar pengenaan pajak pada BPHTB adalah Nilai Perolehan Objek Pajak (NPOP). NPOP adalah besaran nilai/ harga objek pajak yang dipergunakan sebagai dasar pengenaan pajak. Dasar pengenaan Bea Perolehan Hak Atas Tanah dan Bangunan, yang menjadi NPOP dalam jual beli yaitu harga transaksi. Apabila NPOP dalam jual beli yang merupakan harga transaksi tidak diketahui atau lebih rendah dari NJOP yang digunakan dalam pengenaan PBB pada tahun terjadi perolehan, dasar pengenaan yang dipakai adalah NJOP PBB. Untuk asas keadilan, maka apabila atas suatu objek pajak tersebut han- 
ya akan dikenakan pajak atau selisih dari nilai objek pajak dengan nilai batasan tidak kena pajak, salah satunya yaitu Nilai Perolehan Objek Pajak Tidak Kena Pajak (NPOPTKP). NPOPTKP di Kota Mataram ditetapkan sebesar Rp. 60.000.000,00 untuk setiap wajib pajak. Dalam Pasal 88 Undang-Undang Nomor 28 Tahun 2009 dinyatakan bahwa tarif BPHTB ditetapkan paling tinggi 5\%.

Bentuk pelanggaran yang sering dilakukan wajib pajak didaerah Kota Mataram yaitu wajib pajak melakukan pengakuan harga. Pengakuan harga yang dimaksud adalah wajib pajak tidak mencantumkan harga jual beli asli yang telah disepakati antara penjual dengan pembeli, melainkan wajib pajak menggunakan NJOP sebagai dasar pengenaan BPHTB. Dalam Perda Kota Mataram Nomor 12 Tahun 2010 tentang Bea Perolehan Hak Atas Tanah dan Bangunan sudah jelas dikatakan bahwasannya dasar pengenaan BPHTB adalah NPOP, dan nilai perolehan objek pajak dalam jual beli tanah adalah berdasarkan dengan harga transaksi atau nilai pasar. Wajib pajak yang terbukti melakukan hal tersebut maka menurut Pasal 97 ayat (1) huruf a angka 1 Undang-Undang Nomor 28 Tahun 2009 Pemerintah Daerah dapat menerbitkan Surat Ketetapan Pajak Daerah Kurang Bayar (SKPDKB).

\section{Daftar Bacaan}

\section{Buku}

Marihot Pahala Siahaan, Bea Perolehan Hak atas Tanah dan Bangunan (Raja Grafindo Persada 2003).

Marihot Pahala Siahaan, Bea Perolehan Hak Atas Tanah dan Bangunan (BPHTB) Sebagai Pajak Daerah (Sagung Seto 2011).

Marihot Pahala Siahaan, Seri Hukum Pajak Indonesia: Hukum Pajak Formal (Graha Ilmu 2010).

Setu Setiawan, Perpajakan Indonesia Edisi 2009 (Universitas Muhammadiyah Malang Press 2009).

\section{Perundang-undangan}

Undang-Undang Dasar Negara Republik Indonesia Tahun 1945. 
Undang-Undang Nomor 5 Tahun 1960 tentang Peraturan Pokok-Pokok Agraria (Lembaran Negara 1960 - 104, Tambahan Lembaran Negara Nomor 2043).

Undang-Undang Nomor 28 Tahun 2009 tentang Pajak Daerah dan Retribusi Daerah (Lembaran Negara Republik Indonesia Tahun 2009 Nomor 130, Tambahan Lembaran Negara Republik Indonesia Nomor 5049).

Peraturan Daerah Nomor 7 Tahun 2018 tentang Perubahan Kedua Atas Peraturan Daerah Kota Mataram Nomor 12 Tahun 2010 tentang Bea Perolehan Hak Atas Tanah dan Bangunan (Lembaran Daerah Kota Mataram Tahun 2018 Nomor 2 Seri B).

HOW TO CITE: Aldi Luna Ramadhan, 'Pelanggaran Bea Perolehan Hak Atas Tanah Dan Bangunan Dalam Jual Beli Tanah’ (2019) Vol. 2 No. 5 Jurist-Diction. 
--halaman ini sengaja dibiarkan kosong-- 